\title{
Peranan Mulsa Dan Pupuk Organik Terhadap Pertumbuhan Dan Hasil Kacang Tanah (Arachis hypogaea L.) \\ Mulyadi Nurdin', ${ }^{1}$ Khaidir ${ }^{1}$ dan Munazar $^{1}$ \\ ${ }^{1}$ Program StudiAgroekoteknologi, FakultasPertanian, UniversitasMalikussaleh \\ J1. Cot TengkuNieReuleut, MuaraBatu, Aceh Utara \\ Email : mulyadinurdin02@gmail.com
}

\begin{abstract}
Peanut is secondary crops that has the opportunity to develop agroindustry to improve economy sector. In order to assure plants to grow optimally and produce well, it is necessary to provide mulching and organic fertilizer. This study aims to determine of peanut growth and yield using mulching and organic fertilizers. The results showed that mulching giving a very significant effect on plant height at the age of plants 2, 4, 6 and 8 week after planting (WAP) and had a significant effect on the number of leaves at 4 MAP and on the number of plant pods. While the administration of organic fertilizer has a very significant effect on the observation of plant height 2 MAP and number of pods. The interaction between the two factors had a significant effect on the observation of the number of pods and plant height at the age of plants 2 and 8 WAP and had a very significant effect on observing plant height at 6 WAP.
\end{abstract}

\begin{abstract}
ABSTRAK
Kacang tanah merupakan tanaman palawija yang berpeluang dalam pengembangan agroindustri dalam peningkatkan sector ekonomi. Agar tanaman tumbuh secara optimal dan berproduksi dengan baik diperlukan pemberian mulsa dan pupuk organik. Penelitian ini bertujuan untuk mengetahui pertumbunan dan hasil tanaman kacang tanah dengan penggunaan mulsa dan pupuk organik. Hasil penelitian menunjukkan bahwa faktor pemberian mulsa berpengaruh sangat nyata terhadap tinggi tanaman pada umur tanaman 2, 4, 6 dan 8 MST dan berpengaruh nyata terhadap jumlah daun pada 4 MST dan terhadap jumlah polong pertanaman. Sedangkan pemberian pupuk organik berpengaruh sangat nyata pada pengamatan tinggi tanaman 2 MST dan jumlah polong. Interaksi antara kedua faktor memberikan pengaruh nyata pada pengamatan jumlah polong dan tinggi tanaman pada umur tanaman 2 dan 8 minggu setelah tanam (MST) dan berpengaruh sangat nyata pada pengamatan tinggi tanaman pada $6 \mathrm{MST}$.
\end{abstract}

Kata kunci : kacang tanah, mulsa, pupuk organic 


\section{PENDAHULUAN}

Tanaman kacang tanah (Arachis hypogaea, L) telah dilakukan penanaman di Indonesia pada awal abad ke-18 yaitu varietas tipe menjalar (Wijaya, 2011). Kacang tanah sangat berperan sebagai sumber pendapatan bagi petani, karena memiliki peluang pengembangan agroindustri dalam mendukung pembangunan perekonomian daerah yang efisien dan efektif, juga dapat menekan kemiskinan bagi rumah tangga petani dan kelompok masyarakat berpendapatan rendah.

$\begin{array}{rrr}\text { Saat ini bahan } & \text { pangan, } \\ \text { terutama } & \text { sayuran }\end{array}$
dibudidayakan secara organik mulai digandrungi masyarakat. Mereka mimilih makanan ini karena lebih sehat dan lebih aman dari residu pestisida yang mengandung bahan kimia berbahaya. Bahan organik dihasilkan dari budidaya yang dilakukan secara organik, yaitu hanya dipupuk menggunakan kompos dan pupuk organik lainnya. Kandungan hara kompos terbilang lengkap karena mengandung unsur hara makro sekaligus unsur hara mikro. Namun, jumlahnya relatif kecil sehingga untuk bisa memenuhi kebutuhan tanaman diperlukan kompos dalam jumlah banyak.

Namun yang terjadi sekarang ini pertanian secara organik masih memiliki kendala dalam hal peningkatan produksi tanaman seperti kita ketahui pertanian secara organik membutuhkan jumlah pupuk yang yang banyak untuk memenuhi kebutuhan unsur hara bagi tanaman selain itu pupuk organik juga lama tersedia bagi tanaman, maka perlu dilakukan penelitian mengenai hal ini agar pemakaian pupuk organik dapat meningkatkan hasil produksi yaitu dengan memadukan pupuk organik kandang sapi dengan penggunaan mulsa jerami.

Pemakaian mulsa jerami dapat meningkatkan kelembaban tanah sehingga aktivitas mikroorganisme dalam tanah dapat meningkat. Mulsa merupakan material penutup tanaman budidaya yang dimaksudkan untuk menjaga kelembaban tanah serta menekan pertumbuhan gulma dan penyakit sehingga membuat tanaman tersebut tumbuh dengan baik dan optimal. Teknologi pemulsaan dapat mencegah evaporasi, dalam hal ini air yang menguap dari permukaan tanahakan ditahan oleh bahan mulsa dan jatuh kembali ke tanah, akibatnya lahan yang ditanami tidak akan kekurangan air karena penguapan air ke udara hanya terjadi melalui proses transpirasi (Lesmana, 2010). Mulsa dapat berperan mengubah keadaan iklim mikro yang dapat mempengaruhi sifat tanah, menguntungkan untuk pertumbuhan, perkembangan dan peningkatan hasil tanaman (Soewardjo, 1981).

Kotoran sapi memiliki nilai ekonomis karena termasuk pupuk organik yang dibutuhkan oleh semua jenis tumbuh-tumbuhan. Pupuk kandang selain mengandung unsurunsur zat hara serta mineral juga bisa memperbaiki struktur tanah seperti halnya pupuk kompos (Rahardi et al., 1981). Keunggulan pupuk kandang sebenarnya tidak terletak pada kandungan unsur hara karena sesungguhnya pupuk kandang memiliki kandungan hara yang rendah. Kelebihannya ialah pupuk 
kandang dapat meningkatkan humus, memperbaiki struktur tanah, dan meningkatkan kehidupan mikroorganisme (Zulkarnain, 2009).

\section{BAHAN DAN METODE}

Penelitian ini dilaksanakan di desa Paya Puenteut Kecamatan Muara Dua Kota Lhokseumawe. Penelitian ini dimulai dari bulan September sampai dengan November 2015.

Bahan yang digunakan dalam penelitian ini adalah benih kacang tanah, pupuk organik (kotoran sapi), jerami padi dan sekam padi. Alat yang digunakan yaitu : parang, cangkul, meteran, leaf area meter, dan timbangan analitik.

Penelitian ini menggunakan rancangan acak kelompok (RAK) pola faktorial, ada dua faktor yang diteliti yaitu : jenis mulsa (M) dan tingkat pemberian mulsa dan pupuk organik (O).

1. Faktor mulsa (M) terdiri dari 3 taraf yaitu :

$\mathrm{M}_{0}=$ tanpa mulsa

$\mathrm{M}_{1}=$ mulsa jerami

$\mathbf{M}_{2}=$ mulsa sekam padi

2. Faktor pemberian pupuk organik (P) terdiri dari 4 taraf yaitu :

$\mathrm{P}_{0}=$ kontrol/ tanpa penggunaan pupuk organik $\mathrm{P}_{1}=$ penggunaan pupuk kandang sapi $2 \mathrm{~kg} /$ bedeng $\mathrm{P}_{2}=$ penggunaan pupuk kandang sapi $3 \mathrm{~kg} /$ bedeng $\mathrm{P}_{3}=$ Penggunaan pupuk kandang sapi $4 \mathrm{~kg} /$ bedeng

Model matematika yang digunakan untuk Rancangan Acak
Kelompok (Rak) pola faktorial adalah :

$$
\mathrm{Y}_{\mathrm{ijk}}=\mu+\alpha_{\mathrm{i}}+\beta_{\mathrm{j}}+(\mathrm{MP})_{\mathrm{pk}}+\sum_{\mathrm{ijk}}
$$

dimana :

$$
\begin{aligned}
\mathrm{Y}_{\mathrm{ijk}} & =\text { Hasil pengamatan } \\
& \text { faktor mulsa ke-i dan } \\
& \text { pupuk organik ke-j dan } \\
& \text { ulangan ke-k } \\
\mu & =\text { Nilai Tengah } \\
\alpha_{\mathrm{i}} & =\text { Pengaruh faktor mulsa }
\end{aligned}
$$
(M)

$\beta_{\mathrm{j}} \quad=$ Pengaruh faktor pupuk (P)

$\mathrm{MP}_{\mathrm{pk}}=$ Interaksi dari faktor mulsa dan faktor pupuk organik

$\sum_{\mathrm{ijk}} \quad=$ Pengaruh acak

Data diuji dengan analisis ragam, apabila terjadi perbedaan dilakukan uji lanjut dengan menggunakan Duncan's Multiple Range Test (DMRT) pada taraf 5\%

\section{HASIL DAN PEMBAHASAN}

Rekapitulasi hasil analisis ragam menunjukan bahwa faktor pemberian mulsa berpengaruh sangat nyata terhadap tinggi tanaman pada umur tanaman 2, 4, 6, dan 8 MST dan berpengaruh nyata terhadap jumlah daun pada 4 MST dan terhadap jumlah polong pertanaman. Faktor pemberian pupuk berpengaruh sangat nyata pada pengamatan tinggi tanaman 2 MST dan jumlah polong. Interaksi antara kedua faktor memberikan pengaruh nyata pada pengamatan jumlah polong dan tinggi tanaman umur tanaman 2 dan 8 MST dan berpengaruh sangat nyata pada pengamatan tinggi tanaman 6 MST (Tabel 1) 
Tabel 1. Rekapitulasi hasil analisis ragam pengaruh pemberian mulsa (M) dan pemberian pupuk organik $(\mathrm{P})$ serta interaksinya terhadap pengamatan tinggi tanaman, jumlah daun, panjang daun, lebar daun, jumlah polong dan berat 100 biji.

\begin{tabular}{|c|c|c|c|c|}
\hline Tolok ukur & $\begin{array}{l}\text { Pemberian mulsa } \\
\text { (M) }\end{array}$ & $\begin{array}{l}\text { Pemberian pupuk } \\
\text { (P) }\end{array}$ & $\begin{array}{c}\text { Interaksi } \\
(\mathrm{MXP})\end{array}$ & $\begin{array}{l}\mathrm{KK} \\
(\%)\end{array}$ \\
\hline Tinggi tanaman & $* *$ & & & \\
\hline $2 \mathrm{MST}$ & $* *$ & $* *$ & $*$ & 8,92 \\
\hline $4 \mathrm{MST}$ & $* *$ & tn & tn & 13,61 \\
\hline $6 \mathrm{MST}$ & $* *$ & tn & $* *$ & 4,92 \\
\hline $8 \mathrm{MST}$ & $* *$ & tn & $*$ & 2,18 \\
\hline \multicolumn{5}{|l|}{ Jumlah daun } \\
\hline $2 \mathrm{MST}$ & $\operatorname{tn}$ & tn & $\operatorname{tn}$ & 11,12 \\
\hline $4 \mathrm{MST}$ & $*$ & $\operatorname{tn}$ & tn & 7,71 \\
\hline $6 \mathrm{MST}$ & $\operatorname{tn}$ & tn & $\operatorname{tn}$ & 6,89 \\
\hline $8 \mathrm{MST}$ & tn & tn & tn & 7,91 \\
\hline \multicolumn{5}{|l|}{ Panjang daun } \\
\hline $2 \mathrm{MST}$ & $\operatorname{tn}$ & $\operatorname{tn}$ & $\operatorname{tn}$ & 12,19 \\
\hline $4 \mathrm{MST}$ & tn & tn & tn & 11,65 \\
\hline $6 \mathrm{MST}$ & tn & $\operatorname{tn}$ & tn & 11,1 \\
\hline $8 \mathrm{MST}$ & $\operatorname{tn}$ & tn & tn & 8,84 \\
\hline \multicolumn{5}{|l|}{ Lebar daun } \\
\hline $2 \mathrm{MST}$ & $\operatorname{tn}$ & $\operatorname{tn}$ & tn & 13,35 \\
\hline $4 \mathrm{MST}$ & $\operatorname{tn}$ & $\operatorname{tn}$ & $\operatorname{tn}$ & 6,77 \\
\hline $6 \mathrm{MST}$ & tn & tn & tn & 8,89 \\
\hline $8 \mathrm{MST}$ & tn & tn & tn & 10,1 \\
\hline Jumlah Polong & $*$ & $* *$ & $* *$ & 14,65 \\
\hline Berat 100 Biji & $\operatorname{tn}$ & $\operatorname{tn}$ & $\operatorname{tn}$ & 12,86 \\
\hline
\end{tabular}

Keterangan :

$* *=$ berbeda sangat nyata, $*=$ berbeda nyata, $\mathrm{tn}=$ tidak berbeda nyata, $\mathrm{KK}=$ koefisien keragaman

\subsection{Tinggi Tanaman}

Hasil analisis menunjukan penggunaan mulsa dan pupuk kandang sapi berpengaruh terhadap tinggi tanaman pada umur 2, 4, 6 dan 8 MST dan tidak terjadi interaksi pada umur tanaman 4 MST. Ratarata tinggi tanaman kacang tanah pada umur 2, 4, 6, dan 8 minggu setelah tanam akibat penggunaan mulsa yang berbeda dan pupuk kandang disajikan pada Tabel 2. 
Tabel 2. Rata-Rata Tinggi tanaman Kacang Tanah Akibat Penggunaan Mulsa Yang Berbeda dan Dosis Pupuk Kandang Pada Umur 2, 4,6, dan 8 Minggu Setelah Tanam.

\begin{tabular}{lcccc}
\hline \multirow{2}{*}{ Perlakuan } & \multicolumn{4}{c}{ Tinggi Tanaman $(\mathrm{cm})$} \\
\cline { 2 - 5 } & $2 \mathrm{MST}$ & $4 \mathrm{MST}$ & $6 \mathrm{MST}$ & $8 \mathrm{MST}$ \\
\hline MOP0 & $13,80 \mathrm{~d}$ & $16,17 \mathrm{a}$ & 18,73 & 21,03 \\
M0P1 & $16.83 \mathrm{~b}$ & $18,40 \mathrm{a}$ & 20,50 & 23,00 \\
M0P2 & $18,80 \mathrm{~b}$ & $16,83 \mathrm{a}$ & 21,53 & 23,73 \\
M0P3 & $19,87 \mathrm{~b}$ & $21,20 \mathrm{a}$ & 21,93 & 23,93 \\
M1P0 & $18,13 \mathrm{~b}$ & $18,70 \mathrm{a}$ & 22,17 & 24,10 \\
M1P1 & $15,30 \mathrm{c}$ & $20,70 \mathrm{a}$ & 20,40 & 22,60 \\
M1P2 & $15,27 \mathrm{c}$ & $21,90 \mathrm{a}$ & 21,70 & 23,80 \\
M1P3 & $20,43 \mathrm{a}$ & $23,70 \mathrm{a}$ & 22,37 & 23,97 \\
M2P0 & $19,17 \mathrm{ab}$ & $21,70 \mathrm{a}$ & 23,30 & 25,20 \\
M2P1 & $20,70 \mathrm{a}$ & $23,37 \mathrm{a}$ & 24,90 & 26,37 \\
M2P2 & $18,50 \mathrm{~b}$ & $20,23 \mathrm{a}$ & 22,10 & 24,50 \\
M2P3 & $20,13 \mathrm{a}$ & $22,57 \mathrm{a}$ & 23,53 & 26,27 \\
\hline Kenyyy
\end{tabular}

Keterangan :Angka yang diikuti oleh huruf yang sama pada kolom yang sama tidak berbeda nyata berdasarkan uji DMRT pada taraf $0,05 \%$.

Tabel 2 menunjukan bahwa pada penggunaan mulsa dan pemberian pupuk kandang mempengaruhi pertumbuhan terhadap tinggi tanaman pada umur 2, 4, 6, dan 8 MST. Umumnya tanaman tertinggi dijumpai pada perlakuan penggunaan mulsa sekam padi (M2) dan pemberian pupuk kandang sapi 2 kg (P1) baik pada umur 2, 4, 6 dan 8 MST, hal ini dikarenakan pemberian mulsa sekam padi mampu meningkatkan dan mempertahankan kelembaban agar suhu tanah tidak terlalu panas dan tidak terlalu dingin.

Nurhayati Hakim et al., (1986) menjelaskan bahwa salah satu tujuan pemberian mulsa sekam padi adalah menghambat penguapan yang cukup tinggi khususnya pada daerah-daerah tropis. Mulsa yang berasal dari tanaman padi mampu mengurangi pertumbuhan gulma dan dapat menjaga kestabilan kelembaban dalam tanah sehingga mendorong aktivitas mikroorganisme tanah telah aktif dalam mendekomposisi bahan organik untuk mensuplai kebutuhan unsur hara yang dibutuhkan pada pertumbuhan organ vegetatif tanaman (Noorhadi, 2003). Hal ini dikarenakan penggunaan pupuk kandang sapi sudah efisien dan unsur hara yang ada di dalam tanah cukup tersedia bagi tanaman unsur hara Nitrogen.

\subsection{Jumlah Daun}

Hasil analisis ragam menunjukan bahwa perlakuan penggunaan mulsa tidak berbeda nyata terhadap jumlah daun tanaman pada umur 2 MST dan berbeda nyata pada umur 4 MST serta kembali tidak berbeda nyata pada umur 2, 4, 6, dan 8 MST. Rata-rata jumlah daun tanaman kacang tanah pada umur 2, 4, 6, dan 8 MST akibat penggunaan mulsa yang berbeda dapat dilihat pada Tabel 3. 
Tabel 3. Rata-rata Jumlah Daun Tanaman Akibat Penggunaan Mulsa yang Berbeda dan Pemberian Pupuk Kandang Sapi Pada Umur 2, 4, 6, dan 8 MST.

\begin{tabular}{ccccc}
\hline \multirow{2}{*}{ Perlakuan } & \multicolumn{4}{c}{ Jumlah Daun (Helai) } \\
\cline { 2 - 5 } & 2 MST & 4 MST & 6 MST & 8 MST \\
\hline Mulsa & $33,33 \mathrm{a}$ & $46,58 \mathrm{c}$ & $61,67 \mathrm{a}$ & $89,17 \mathrm{a}$ \\
\hline MO & $34,67 \mathrm{a}$ & $49,67 \mathrm{~b}$ & $62,50 \mathrm{a}$ & $92,42 \mathrm{a}$ \\
M1 & $35,92 \mathrm{a}$ & $51,50 \mathrm{a}$ & $62,25 \mathrm{a}$ & $93,83 \mathrm{a}$ \\
M2 & $35,11 \mathrm{a}$ & $49,44 \mathrm{a}$ & $62,56 \mathrm{a}$ & $88,89 \mathrm{a}$ \\
\hline Pupuk & $34,00 \mathrm{a}$ & $48,44 \mathrm{a}$ & $63,33 \mathrm{a}$ & $92,78 \mathrm{a}$ \\
P0 $13,33 \mathrm{a}$ & $48,44 \mathrm{a}$ & $63,56 \mathrm{a}$ & $92,22 \mathrm{a}$ \\
P2 & $35,11 \mathrm{a}$ & $50,22 \mathrm{a}$ & $63,11 \mathrm{a}$ & $93,33 \mathrm{a}$ \\
\hline P3 & &
\end{tabular}

Keterangan : Angka yang diikuti oleh huruf yang sama pada kolom yang sama tidak berbeda nyata berdasarkan uji DMRT pada taraf $0,05 \%$.

Tabel 3 menunjukan bahwa perlakuan penggunaan mulsa tidak berbeda nyata terhadap jumlah daun tanaman pada umur 2 MST dan berbeda nyata pada umur 4 MST serta kembali tidak berbeda nyata pada umur 6 dan 8 MST. Namun jumlah daun terbanyak dijumpai pada perlakuan penggunaan mulsa sekam padi (M2) hal ini diduga karena suhu tempat tumbuh tanaman sudah ideal untuk pertumbuhan kacang tanah sehingga fungsi mulsa tidak lagi dimanfaatkan oleh tanaman. Selanjutnya pada Tabel 3 juga menunjukan bahwa perlakuan penggunaan pupuk kandang sapi tidak berbeda nyata terhadap jumlah daun tanaman pada umur 2 dan 4 MST dan berbeda nyata pada umur 6 dan 8 MST. Jumlah daun terbanyak dijumpai pada perlakuan pupuk kandang sapi $4 \mathrm{~kg} /$ bedeng (P3) hal ini dikarenakan penggunaan pupuk kandang sapi sudah efektif dan mampu memenuhi kebutuhan unsur hara pada saat dibutuhkan.

Pertumbuhan tanaman tidak hanya ditentukan oleh tinggi tanaman kacang tanah, tetapi jumlah daun dapat dijadikan sebagai indikator untuk menentukan pertumbuhan kacang tanah. Pembentukan daun berawal dari pembelahan sek yang terjadi didekat apeks tajuk yang kemudian diikuti primordiannya (Salisbury, 1995).

Peningkatan jumlah daun yang disebkan oleh peranan dari unsur $\mathrm{N}$ yang terdapat dalam pupuk kandang Hartatik (2006), menyatakan nitrogen yang berasal dari pupuk kandang umumnya dirubah menjadi bentuk nitrat tersedia sehingga mudah larut dan bergerak pada daerah perakaran tanaman.

Dalam pembentukan daun diperlukan adanya unsur hara yang cukup agar jumlah daun yang dihasilkan banyak. Dengan adanya pemberian pupuk dapat meningkatkan jumlah daun. Selain unsur $\mathrm{N}$ dan $\mathrm{K}$ pupuk kandang juga mengandung unsur hara $\mathrm{Mg}$, adanya kandungan unsur hara $\mathrm{Mg}$ dapat lebih meningkatkan jumlah daun.

Hasil penelitian Supriyadi (2001), menyatakan bahwa tanaman 
yang diberi pupuk oraganik yang mengandung unsur hara $\mathrm{Mg}$ menghasilkan jumlah daun lebih banyak dibandingkan tanpa pupuk $\mathrm{Mg}$, ini dikarenakan unsur $\mathrm{Mg}$ merupakan penyusunan pigmen klorofil pada tanaman yang berperan mengambil dan mengubah energi cahaya menjadi bentuk yang dapat digunakan dalam proses fotosintesis.

\subsection{Panjang Daun}

Hasil analisi ragam menunjukan bahwa perlakuan mulsa dan pemberian pupuk kandang tidak memberikan pengaruh terhadap jumlah daun tanaman kacang tanah. Namun pemberian mulsa dan pupuk kandang dapat meningkatkan panjang daun tanaman kacang tanah dari umur 2, 4, 6. dan 8 MST. Tidak terdapat interaksi antara perlakuan pemberian mulsa dan pupuk kandang sapi terhadap panjang daun tanaman kacang tanah pada umur 2,4, 6, dan 8 MST. Rata-rata panjang daun tanaman kacang tanah pada umur 2, 4, 6 dan 8 MST akibat penggunaan mulsa yang berbeda disajikan pada Tabel 4.

Tabel 4. Rata-rata Panjang Daun Tanaman Akibat Penggunaan Mulsa yang Berbeda dan Pemberian Pupuk Kandang Sapi Pada Umur 2, 4, 6, dan 8 Minggu Setelah Tanam.

\begin{tabular}{ccccc}
\hline Perlakuan & \multicolumn{5}{c}{ Panjang Daun $(\mathrm{cm})$} \\
\cline { 2 - 5 } & 2 MST & 4 MST & 6 MST & 8 MST \\
\hline Mulsa & $1,89 \mathrm{a}$ & $2,55 \mathrm{a}$ & $3,45 \mathrm{a}$ & $4,06 \mathrm{a}$ \\
MO & $1,94 \mathrm{a}$ & $2,63 \mathrm{a}$ & $3,38 \mathrm{a}$ & $4,26 \mathrm{a}$ \\
M1 & $2,00 \mathrm{a}$ & $2,86 \mathrm{a}$ & $3,57 \mathrm{a}$ & $4,76 \mathrm{a}$ \\
\hline M2 & $1,87 \mathrm{a}$ & $2,60 \mathrm{a}$ & $3,32 \mathrm{a}$ & $4,34 \mathrm{a}$ \\
\hline Pupuk & $1,97 \mathrm{a}$ & $2,59 \mathrm{a}$ & $3,46 \mathrm{a}$ & $4,22 \mathrm{a}$ \\
P0 & $1,99 \mathrm{a}$ & $2,74 \mathrm{a}$ & $3,36 \mathrm{a}$ & $4,47 \mathrm{a}$ \\
P2 & $1,96 \mathrm{a}$ & $2,78 \mathrm{a}$ & $3,44 \mathrm{a}$ & $4,40 \mathrm{a}$ \\
\hline P3 &
\end{tabular}

$\overline{\text { Keterangan : Angka yang diikuti oleh huruf yang sama pada kolom yang sama }}$ tidak berbeda nyata berdasarkan uji DMRT pada taraf $0,05 \%$.

Tabel 4 menunjukkan bahwa perlakuan pemberian mulsa dapat meningkatkan panjang daun tanaman kacang tanah. Pemberian mulsa jerami maupun mulsa sekam padi dapat meningkatkan panjang daun. Pemberian sekam mulsa sekam padi maupun mulsa jerami mempunyai efek yang lebih dibandingkan dengan tanpa pemberian mulsa. Mulsa akan terlihat pengaruhnya, apabila kondisi lingkungan tumbuh mengalami cekaman kekeringan.
Selain pemberian mulsa, pupuk kandang juga dapat mempengaruhi pertumbuhan panjang daun tanaman kacang tanah. Meningkatnya panjang daun disebabkan oleh peranan unsur hara yang diperoleh dari pemberian pupuk kandang. Pupuk kandang memiliki unsur hara yang tergolong lengkap , tetapi tidak semuanya dapat dimanfaatkan oleh tanaman, sebagian besar hilang karena proses pencucian dari dekomposisi anaerob, terutama unsur-unsur N-Pdan K (Sitepu, 2004). 
Unsur $\mathrm{N}$ merupakan unsur hara yang diperlukan untuk pemberian bibit kelapa sawit khususnya dalam pembentukan dan mempercepat pertumbuhan panjang daun tanaman kacang tanah (Sutedjo, 1994).

Komposisi pupuk kandang selain mengandung unsur ahra N-P$\mathrm{K}$ juga tersedia unsur hara mikro lengkap. Unsur hara mikro tersebut sangat dibutuhkan oleh kacang tanah dalam jumlah yang sedikit, meskipun kebutuhan sedikit tetapi kekahatan unsur mikro dapat menghambat pertumbuhan kacang tanah.

\subsection{Lebar Daun}

Hasil analis ragam menunjukan bahwa perlakuan penggunaan mulsa tidak berbeda nyata terhadap indeks luas daun tanaman. Rata-rata indeks luas daun tanaman kacang tanah pada umur 2, 4, 6, dan 8 MST akibat penggunaan mulsa yang berbeda disajikan pada Tabel 5.

Tabel 5. Rata-rata Lebar Daun Tanaman Akibat Penggunaan Mulsa Yang Berbeda dan Pemberian Pupuk Kandang Sapi Pada Umur 2, 4, 6, dan 8 Minggu Setelah Tanam.

\begin{tabular}{|c|c|c|c|c|}
\hline \multirow{2}{*}{$\begin{array}{c}\text { Perlakuan } \\
\text { Mulsa }\end{array}$} & \multicolumn{4}{|c|}{ Lebar Daun $(\mathrm{cm})$} \\
\hline & $2 \mathrm{MST}$ & 4 MST & $6 \mathrm{MST}$ & $8 \mathrm{MST}$ \\
\hline MO & 1,31 & 1,57 & 1,84 & 2,18 \\
\hline M1 & 1,31 & 1,58 & 1,84 & 2,24 \\
\hline M2 & 1,40 & 1,60 & 1,90 & 2,28 \\
\hline \multicolumn{5}{|l|}{ Pupuk } \\
\hline P0 & 1,28 & 1,52 & 1,79 & 2,16 \\
\hline $\mathrm{P} 1$ & 1,30 & 1,36 & 1,82 & 2,26 \\
\hline $\mathrm{P} 2$ & 1,36 & 1,62 & 1,93 & 2,26 \\
\hline P3 & 1,42 & 1,61 & 1,90 & 2,26 \\
\hline
\end{tabular}

Keterangan :Angka yang diikuti oleh huruf yang sama pada kolom yang sama tidak berbeda nyata berdasarkan uji DMRT pada taraf $0,05 \%$.

Tabel 5 menunjukan bahwa perlakuan mulsa tidak berbeda nyata pada lebar dau tanaman. Namun lebar daun terluas dijumpai pada perlakuan mulsa sekam padi (M2) hal ini diduga bahwa suhu tanah di lokasi penelitian cukup tinggi karena tidak adanya hujan maka diawal pertumbuhan tanaman, pemberian mulsa organik tidak efektif. Namun di masa pertumbuhan tanaman beradaptasi dengan suhu tanah disekitar tanaman dan unsur hara yang diberikan fungsi mulsa efektif di masa pertumbuhan tanaman.
Aplikasi mulsa sekam padi dan mulsa jerami mampu meningkatkan pertumbuhan lebar daun kacang tanah pada setiap umur dibanding tanpa perlakuan mulsa. Pemberian mulsa sekam padi mempunyai efek yang lebih dibandingkan dengan tanpa pemberian mulsa. Meningkatnya laju lebar daun tanaman ini diduga salah satunya disebabkan karena dengan menggunakan penggunaan mulsa sekam padi maupun mulsa jerami yang berpengaruh besar terhadap vegetasi tanaman, sehingga tanaman 
dapat tumbuh dan berkembang dengan baik karena dapat menyerap kandungan unsur hara, air, serta cahaya melalui proses fotosintesis.

Berpengaruhnya perlakuan pemberian mulsa ini juga sangat ditunjangpada keadaan lengas tanah sehingga dengan pemberian mulsa diperoleh hasil lebih baik dibanding tanpa pemberian mulsa. Budidaya tanaman dengan mulsa akan menyebabkan rata-rata pori aerasi tanah sedikit lebih sedikit dibandingkan tanpa mulsa. Pemakaian mulsa dapat meningkatkan suhu minimum dan menurunkan suhu maksimum tanah karena bahan organik yang mempunyai koefisien konduktivitas panas relatif lebih kecil dibandingkan dengan tanah mineral (Sinakuban, 1986). Pemberian mulsa dapat mencegah kehilangan air melalui evaporasi, memperkecil proses dispersi, merangsang agregasi tanah, memperbaiki struktur tanah, mempertahankan kapasitas pegang air, dan memelihara kecepatan infiltrasi.

Lebar daun kacang tanah dapat ditentukan berdasarkan panjang dan lebar dan pemberian pupuk kandang dengan kandungan unsur hara yang banyak dapat meningkatkan indeks luas daun kacang tanah, unsur hara N-P-K yang terkadung dalam pupuk kandang berperan dalam pertumbuhan indeks luas daun sehingga dapat lebih cepat mencapai titik kritikal pertumbuhan.

Komposisi pupuk kandang mempunyai kandungan unsur hara $\mathrm{K}$. Unsur hara $\mathrm{K}$ mempunyai peranan penting sebagai katalisator , terutama di dalam penguraian protein menjadi asam amino, serta penyusunan dan pembongkaran karbohidrat (Solvia dan Sutater, 1997). Kalium juga berperan dalam proses fisilogi tanaman, pembukaan stomata, mengaktifkan enzim dan mempengaruhi penyerapan unsurunsur hara (Hardjowigeno, 2003).

Panjang daun dan lebar berhubungan dengan indeks luas daun, menurut Hidayat (1995), daun merupakan tempat terjadinya proses fotosintesis dan proses metabolisme lainnya, jika indeks luas daun leboh besar maka kemampuan daun untuk berfotosintesis semakin besar pula dan karbohidrat yang dihasilkan juga lebih banyak. Karbohidrat dari proses fotosintesis tersebut akan digunakan untuk meningkatkan panjang daun kacang tanah.

Penggunaan mulsa oragnik tidak menghambat pertumbuhan tanaman ke permukaan, adanya peningkatan pertumbuhan tanaman juga disebabkan persediann akan unsur hara terpenuhi bagi pertumbuhan tanaman (Nurhayati et al.,1986).

Tabel 5 juga menunjukan bahwa pemberian perlakuan penggunaan pupuk kandang sapi tidak berbeda nyata terhadap lebar daun tanaman, namun lebar daun terluas dijumpai pada perlakuan penggunaan pupuk kandang sapi 3 $\mathrm{kg} /$ bedeng (P2) hal ini dikarenakan bahwa ada kecendrungan fotosntesis yang meningkat, karena adanya penambahan unsur hara di dalam tanah.

Poerwowidodo

menyatakan bahwa protein merupakan penyusun utama 
protoplasma yang berfungsi sebagai pusat proses metabolisme dalam tanah yang selanjutnya akan memacu pembelahan dan pemanjangan sel. Unsur hara Nitrogen dan unsur hara mikron tersebut berperan sebagai penyusun klorofil sehingga meningkatkan aktivitas fotosintesis tersebut akan perkebangan pada jaringan meristematis daun.

\subsection{Jumlah Polong}

Hasil analisis ragam menunjukan bahwa penggunaan mulsa berbeda nyata terhadap jumlah polong tanaman. Rata-rata jumlah polong kacang tanah akibat penggunaan mulsa yang berbeda disajikan pada Tabel 6.

Tabel 6. Rata-Rata Jumlah Polong Akibat Penggunaan Mulsa Yang Berbeda dan Dosis Pupuk Kandang Sapi.

\begin{tabular}{cc}
\hline Perlakuan & Jumlah Polong \\
\hline M0P0 & $22,33 \mathrm{~cd}$ \\
M0P1 & $22,66 \mathrm{bcd}$ \\
M0P2 & $28,33 \mathrm{bc}$ \\
M0P3 & $28,00 \mathrm{bc}$ \\
M1P0 & $24,00 \mathrm{bcd}$ \\
M1P1 & $21,33 \mathrm{~d}$ \\
M1P2 & $25,66 \mathrm{bcd}$ \\
M1P3 & $27,00 \mathrm{bcd}$ \\
M2P0 & $27,66 \mathrm{bcd}$ \\
M2P1 & $29,00 \mathrm{~b}$ \\
M2P2 & $23,00 \mathrm{bcd}$ \\
M2P3 & $35,33 \mathrm{a}$ \\
\hline
\end{tabular}

Keterangan : Angka yang diikuti oleh huruf yang sama pada kolom yang sama tidak berbeda nyata pada uji DMRT taraf $0,05 \%$
Tabel 6 menunjukan bahwa terdapat interaksi antara perlakuan penggunaan mulsa dengan pupuk kandang sapi pada jumlah polong tanaman, namun jumlah polong paling bnayak dijumpai pada perlakuan penggunaan mulsa sekam padi dan pupuk kandang $4 \mathrm{~kg} /$ bedeng ( M2P3) hal ini berarti bahwa pada keadaan yang relatif tercekam pengaruh penggunaan pupuk kandang sapi baru nampak pada pemupukan yang cukup tinggi, Kartasapoetra (2005) menyatakan bahwasannya kebutuhan tanaman akan bermacam-macam unsur hara selama pertumbuhan dan perkembangan adalah tidak sama, namun membutuhkan waktu yang berbeda dan tidak sama banyknya. Santoso dan Adisarwanto (1993), mengatakan bahwa pemberian mulsa mampu meningkatkan hasil kacang tanah 30-40\% lebih tinggi dibandingkan tanpa pemberian mulsa. Dengan kata lain, tanaman kacang tanah dapat berproduksi secara maksimal dari awal pertumbuhan hingga fase generativ.

Peningkatan jumlah polong tanaman kacang tanah juga dipengaruhi oleh penggunaan mulsa sekam padi mampu mempertahankan kelembaban untuk pertumbuhan kacang tanah khususnya untuk jumlah polong, dengan meningkatkan jumlah pori makro, aerasi , menjadi lebih lebih baik dan merangsang pertumbuhan serta perkembangan akar sehingga tanaman dapat menyerap hara dan air dalam jumlah yang cukup.

Pengaruh mulsa organik ditunjukan untuk kepentingan agronomi, yaitu mempertahankan tingkat kelembaban tanah, menjaga 
suhu permukaan tanah, mengurangi erosi, memperlambat pemiskinan $\mathrm{P}$ dan $\mathrm{Si}$, meningkatkan C-Organik, $\mathrm{Mg}$ dan KTK, meningkatkan serpan $\mathrm{P}$ dan $\mathrm{K}$, meningkatkan stabilitas agregat tanah serta translokasi $\mathrm{N}$ dan P.

\subsection{Berat 100 Biji}

Hasil sidik ragam menunjukan bahwa perlakuan penggunaan mulsa todak berbeda nyata terhadap berat 100 biji. Rata-rata berat 100 biji akibat penggunaan mulsa yang berbeda disajikan pada Tabel 7 .

Tabel 7. Rata-Rata Barat 100 Biji Akibat Penggunaan Mulsa Yang Berbeda dan Dosis Pupuk Kandang Sapi.

\begin{tabular}{|c|c|}
\hline Perlakuan & Berat 100 biji (g) \\
\hline \multicolumn{2}{|l|}{ Mulsa } \\
\hline M0 & 50,1 \\
\hline M1 & 52,16 \\
\hline M2 & 51,29 \\
\hline \multicolumn{2}{|l|}{ Pupuk } \\
\hline p0 & 50,52 \\
\hline p1 & 51,37 \\
\hline p2 & 52,55 \\
\hline p3 & 50,29 \\
\hline Keterangan & $\begin{array}{l}\text { Angka yang diikuti } \\
\text { oleh huruf yang sama } \\
\text { pada kolom yang } \\
\text { sama tidak berbeda } \\
\text { nyata pada uji DMRT } \\
\text { taraf } 0,05 \%\end{array}$ \\
\hline
\end{tabular}

Tabel 7 menunjukan bahwa rata-rata berat 100 biji tertingi diperoleh pada perlakuan penggunaan mulsa jerami (M1). Berat 100 biji terendah diperoleh pada perlakuan tanpa mulsa, hal ini disebabkan oleh bnayaknya iar yang yang diserap oleh tanaman dari awal penanaman sampai masa pembungaan dan saat panen sehingga sangat berpengaruh pada peningkatan jumlah polong khususnya unruk berat 100 biji, serta terjadinya kompetisi pengambilan unsur hara antara tanaman kacang tanah dengan gulma yang tumbuh di areal pertanaman ataupun sedikitnya gulma yang tumbuh pada areal pertanaman kacang tanah sehingga tidak memberikan perbedaan nyata pada berat 100 biji.

Tabel 7 menunjukan bahwa perlakuan penggunaan pupuk kandang sapi tidak berbeda nyata pada berat 100 biji, namun berat 100 biji terberat dijimpai pada perlakuan penggunaan pupuk kandang sapi 3 $\mathrm{kg} /$ bedeng ( P2). Berat 100 biji terendah dijumpai pada pengunaan pupuk kandang sapi 6 ton/ha (P3), hal ini dikarenakan penggunaan pupuk kandang sapi yang cukup tinggi akan mengakibatkan kekosongan polong kacang tanah sehingga menyebabkan kekeringan pada polong.

\section{KESIMPULAN DAN SARAN}

\subsection{Kesimpulan}

Berdasarkan hasil penelitian yang dilakukan, maka dapat kesimpulan sebagai berikut :

1. Pemberian mulsa berpengaruh sangat nyata terhadap tinggi tanaman pada umur tanaman 2, 4 . 6 dan 8 MST dan terhadap jumlah polong pertanaman. Pemakaian mulsa organik (mulsa jerami dan mulsa sekam padi) dapat meningkatkan pertumbuhan tanaman kacang tanah dibandingkan dengan tanpa pemberian mulsa. 
2. Pemberian pupuk berpengaruh sangat nyata pada pengamatan tinggi tanaman umur 2 MST dan jumlah polong

3. Interaksi antara kedua faktor memberikan pengarauh nyata pada pengamatan jumlah polong dan tinggi tanaman umur tanaman 2 dan 8 MST dan berpengaruh sangat nyata pada pengamatan tinggi tanaman $6 \mathrm{MST}$.

\subsection{Saran}

Untuk meningkatkan hasil produksi kacang tanah disarankan kepada petani budidaya kacang tanah untuk menggunakan mulsa organik seperti mulsa jerami padi dan mulsa sekam padi serta penggunaan dosis pupuk kandang yang tepat.

\section{DAFTAR PUSTAKA}

Kasno, A., A. Winarto, dan Sunardi. 1993. Kacang Tanah. Departemen Pertanian. Badan Penelitian dan Pengembangan Pertanian. Pusat Penelitian dan Pengembangan Tanaman Pangan. Balai Penelitian Tanaman Pangan. Malang. 315 hal.

Marsono. 2001. Pupuk Akar. Penebar Swadaya. Jakarta

Noorhadi dan Sudadi. 2003. Kajian Pemberian Air dan Mulsa Terhadap Iklim Mikro Pada Tanaman Cabai di Tanah Entisol. Jurnal Ilmu Tanah dan Lingkungan, Vol 4 (1) (2003) pp 41-49. Fakultas Pertanian UNS, Surakarta.

Novizan. 2007. Petunjuk Pemupukan yang Efektif. Agro Media Pustaka. Jakarta
Nurhayati Hakim. M. Yusuf Nyakpa. A. M. Lubis Sutopo. M. Rusti Saul. M. Amin Diha. Go Bang Hong dan H.H. Bailey. 1986. Dasar-Dasar Ilmu Tanah. Universitas Lampung.

Pitojo, S. 2005. Benih Kacang Tanah. Kanisius. Yogyakarta. 75 hal.

Purwowidodo. 1991. Ganesa Tanah. Rajawali. Jakarta.

Purwowidodo. 1992. Teknologi Mulsa. Dewaruci Press. Jakarta.

Rahardi , F., Sri, N, dan Eko M. 1995. Bercocok Tanam Dalam Pot. Penebar Swadaya. Jakarta

Safan. 2008. Produksi Enzim Selulase oleh Aspergillusniger dengan Substrat Jerami dalam Solid State Fermentation. Wordpress. Com. Diakses pada selasa, 02/05/15 pukul 22.50.

Santoso Singgih, 2002. Statistik Parametrik, Cetakan Ketiga, PT Gramedia Pustaka Utama. Jakarta.

Suprapto, H.S. 2004. Bertanam Kacang Tanah. Penebar Swadaya. Jakarta. 32 hal.

Wijaya, A. 2011. Pengaruh Pemupukan dan Pemberian Kapur terhadap pertumbuhan dan daya hasil kacang tanah (Arachies hypogea L). Skripsi. Fakultas Pertanian Institute Pertanian Bogor. Bogor. 
Zulkarnain. 2009. Dasar-Dasar

Jakarta. 336 hlm.

Hortikultura. PT. Bumi Aksara. 